\title{
Environmental characterization and impacts of fish farming in the cascade reservoirs of the Paranapanema River, Brazil
}

\author{
Roberto Montanhini Neto*, Helder Rafael Nocko, Antonio Ostrensky
}

Integrated Group of Aquaculture and Environmental Studies, Federal University of Paraná, 80035-050, Curitiba, Paraná, Brazil

\begin{abstract}
The goal of this study was to characterize current water quality, simulate water quality in 8 large artificial reservoirs occurring along the course of the Paranapanema River, Brazil, and estimate fish production in the region to assess the impacts of this production on the local aquatic environment. Primary data describing the bottom sediments and water quality, and time series recorded between 2001 and 2011 were used. Water quality was modeled to simulate the trophic state index (TSI) for each reservoir, and 37 fish cage farms along the length of those reservoirs were identified. Only one-third of these farms had environmental licensing for regular operations. The potential increase in fish production was estimated to exceed $250 \%$ in the short to medium term. The concentrations of nutrients (organic matter, nitrogen, and phosphorus) present in the bottom sediment beyond areas of fish production were similar to those found in areas distant from the fish farms. The TSI results indicated that the reservoirs could be classified between oligotrophic and mesotrophic. The few eutrophied areas represented approximately $1 \%$ on average of the total area of the reservoirs. The reservoirs of the Paranapanema River have adequate water quality standards for aquaculture, and there is no indication that this activity is currently causing significant impacts to the overall aquatic environment in each reservoir. Nevertheless, caution is required when selecting areas for new fish farms to avoid areas that are more susceptible to eutrophication.
\end{abstract}

KEY WORDS: Fish cage farming $\cdot$ Tilapia $\cdot$ Trophic state $\cdot$ Bottom sediment $\cdot$ Water quality

\section{INTRODUCTION}

Aquaculture is considered a viable source of relatively cheap protein of high biological value, especially in developing countries where protein is scarce (El-Gayar \& Leung 2000). Therefore, artificial lakes and reservoirs are being increasingly used for fish farming (Ayer \& Tyedmers 2009, Barton \& Floysand 2010). According to Cowx et al. (1998) and Borges et al. (2010), fish production in artificial reservoirs has the potential to significantly contribute to the global fish supply, especially in Asia (De Silva 2002) and South America (Petrere 1996).

\footnotetext{
${ }^{*}$ Corresponding author: roberto.neto@ufpr.br
}

In addition to food production, the expansion of aquaculture in artificial reservoirs benefits local economies by generating employment and income along the entire aquaculture production chain (Ross et al. 2011), representing an important production alternative for populations affected by the construction of dams (Abery et al. 2005). However, this activity can have a significant impact on aquatic environments (Garcia et al. 2014, Li et al. 2014), and minimizing these risks requires planning, legislating compliance, and managing and monitoring the environmental quality of the fish farms (Nyanti et al. 2012, Ling et al. 2013, Ramos et al. 2013).

() The authors 2015. Open Access under Creative Commons by Attribution Licence. Use, distribution and reproduction are unrestricted. Authors and original publication must be credited. 
In Brazil, the use of reservoirs for fish cage farming has significantly grown in recent years (Dias et al. 2011) because of the regularization of the multiple use of reservoirs, including aquaculture. This regularization was achieved through the establishment of the National Water Resources Policy in 1997 (Bueno et al. 2013), and more specifically by Law No. 9.433, Decree-law No. 4.895 of 2003, and Interministerial Normative Ruling No. 6 of 2004 (Brazil 2004). The Interministerial Normative Ruling No. 7 of 2005 was also an important landmark and determined that up to $1 \%$ of the aquatic environment area of Brazil can be used for aquaculture (Brazil 2005a).

The Paranapanema River is a tributary of the Paraná River (Prata River Basin). Located between latitude $22^{\circ}$ and $26^{\circ} \mathrm{S}$ and longitude $47^{\circ}$ and $54^{\circ} \mathrm{W}$, this river runs in an east-west direction between 809 and $239 \mathrm{~m}$ altitude, and it forms a basin of approximately $100800 \mathrm{~km}^{2}$ (Jorcin \& Nogueira 2008). The Paranapanema River is $930 \mathrm{~km}$ long and forms the border between the southeast and south regions of Brazil (Fig. 1). The river has 8 large reservoirs (Jurumirim, Chavantes, Salto Grande, Canoas II, Canoas I, Capivara, Taquaruçu, and Rosana), which are projected to be the targets of a broad-scope program by the Brazilian government to establish aquaculture parks for fish cage farming over the next few years.

However, aquaculture is an anthropic activity that has not easily met the requirements of environmental sustainability (Eler \& Millani 2007), especially when conducted in large reservoirs (Deus et al. 2013, Garcia et al. 2014). One of the environmental changes more commonly associated with freshwater aquaculture is eutrophication (Black 2000). The solid (feed leftovers and feces) and soluble (renal excretions and endogenous losses) residues resulting from fish farming production processes are directly released into the reservoir water and may promote increased concentrations of nutrients, especially phosphorus and nitrogen (Montanhini \& Ostrensky 2013). Depending on the input of these nutrients into the environment, plankton communities may change significantly, which can lead to an imbalance of the aquatic ecosystem and gradual degradation of water quality. One of the effects commonly associated with this change is a decrease in local dissolved oxygen concentrations, which compromises the survival of both farmed fish and local native fauna (Demir et al. 2001, Conley et al. 2009, Guo et al. 2009).

The goal of the present study was to gather information to identify areas that are better suited for the establishment of reservoirs, plan reservoir use for aquaculture, and monitor the environmental quality of aquaculture parks that the Brazilian government intends to install in the large reservoirs of the Paranapanema River. More specifically, the present study aimed to (1) characterize the aquaculture enterprises already installed on the studied reservoirs along with their development prospects; (2) characterize the current standards of water quality and nutrient con-
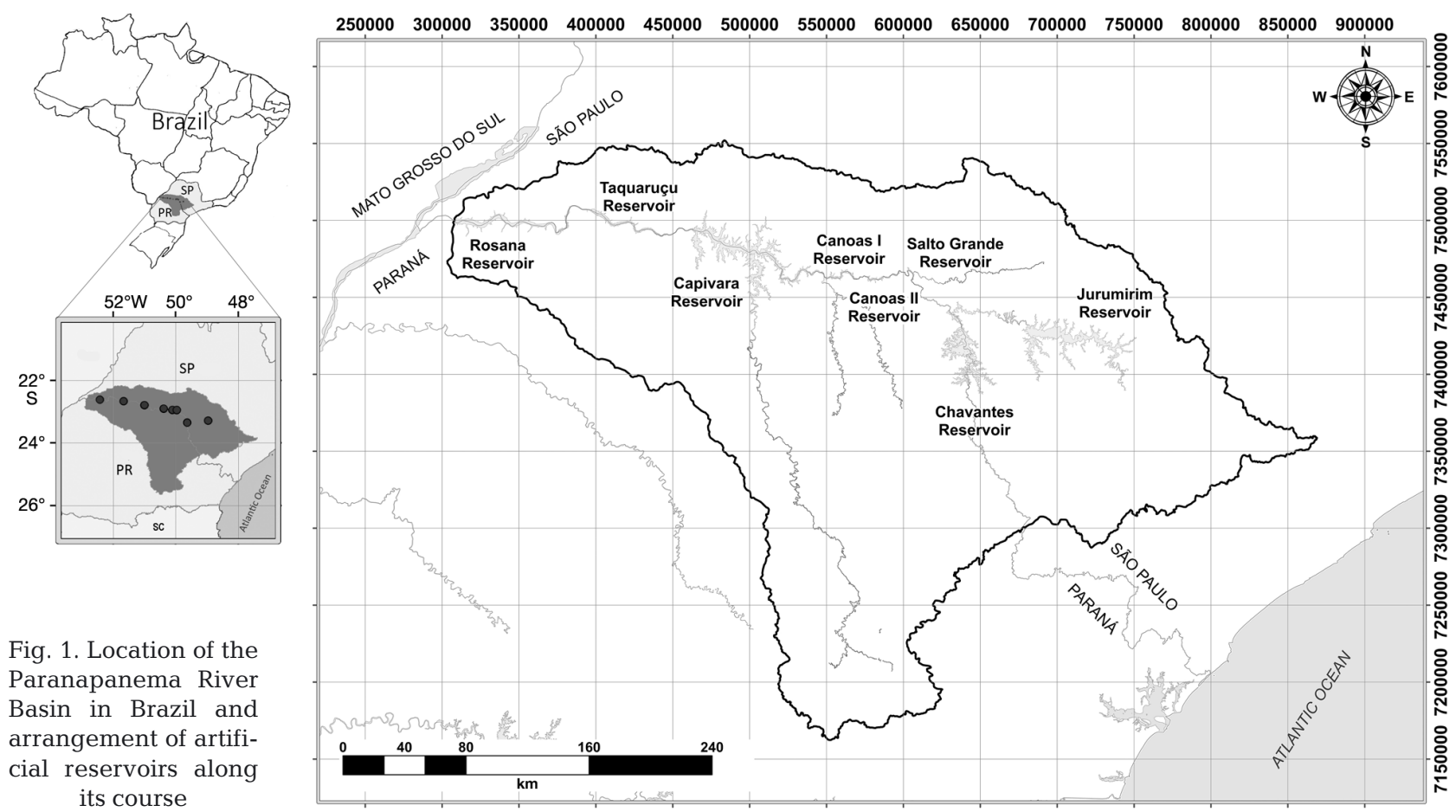

Fig. 1. Location of the Paranapanema River Basin in Brazil and arrangement of artificial reservoirs along its course 
centration in the bottom sediment associated with these enterprises; and (3) determine the trophic state index (TSI) along the entire length of the reservoirs and evaluate the level of environmental impact caused by the active aquaculture enterprises.

\section{MATERIALS AND METHODS}

\section{Study region}

The main characteristics of the Paranapanema River dams and their respective artificial reservoirs are presented in Table 1. The Paranapanema River Basin is divided into 3 regions that have 8 large hydroelectric dams arranged in a cascade: high Paranapanema region, where the Jurumirim and Chavantes reservoirs are located; medium Paranapanema region (Salto Grande, Canoas II, Canoas I, and Capivara reservoirs); and low Paranapanema region (Taquaruçu and Rosana reservoirs; Felisberto \& Rodrigues 2005, Duke Energy Brasil 2013).

Three of these dams (Jurumirim, Chavantes, and Capivara) are storage dams with a remarkable dendritic morphology, and they store the largest volumes of water. The remaining dams are characterized by reduced water retention time and display a more river-like shape and run-of-the-river regime (Salto Grande, Canoas II, Canoas I, Taquaruçu, and Rosana; Table 1). Oligo-mesotrophic conditions with a tendency toward mesotrophic conditions predominate in these reservoirs (Nogueira \& Jorcin 2006).

\section{Characterization of fish farming in the studied region}

The entire length of all of the studied reservoirs was surveyed by boat to identify, georeference, and characterize the aquaculture enterprises already installed, either legally or informally, in the reservoirs of the Paranapanema River. As the active enterprises were identified, the respective technical managers and/or owners were contacted and asked to participate in a questionnaire on their production systems, zootechnical parameters, and projections for the following years.

Information on the licensing proceedings of aquaculture enterprises filed with the Ministry of Fisheries and Agriculture (Ministério da Pesca e Aquicultura, MPA) was obtained using the information system for permits of Brazilian water use for aquaculture purposes (Sistema de informação das autorizações de uso das águas de domínio da União para fins de aquicultura - SINAU/MPA; Brazil 2004, 2014). This system concentrates and manages all public water use requests for the installation of aquaculture projects in Brazil. These data provided an overview of the interest in establishing aquaculture areas in the reservoirs and allowed for a projection of the medium- to short-term growth of fish farming in the region.

\section{Analyses of bottom sediment}

A 1750-G30 Petersen grab sampler (Cole-Parmer) was used to collect sediment samples from 50 points located in the main channels, arms, and margins of the reservoirs and directly from the fish farming areas. Sampling at the fish farming areas was always performed close to the center of the fish farm.

Samples were stored in plastic packages, labeled, and sent to the laboratory. Phosphorus concentrations were determined through a reduction of ammonium molybdate and potassium antimony tartrate in the presence of ascorbic acid in acid medium (APHA

Table 1. Morphometric characteristics of the Paranapanema River reservoirs. Adapted from Felisberto \& Rodrigues (2005) and Duke Energy Brasil (2013). OT: oligotrophic, ET: eutrophic, MT: mesotrophic

\begin{tabular}{|c|c|c|c|c|c|c|c|c|c|}
\hline Reservoir & Geographical location & $\begin{array}{l}\text { Opening } \\
\text { (year) }\end{array}$ & $\begin{array}{c}\text { Nominal } \\
\text { power } \\
(\mathrm{MW})\end{array}$ & $\begin{array}{c}\text { Total } \\
\text { length } \\
(\mathrm{km})\end{array}$ & $\begin{array}{c}\text { Mean } \\
\text { depth } \\
(\mathrm{m})\end{array}$ & $\begin{array}{l}\text { Maximum } \\
\text { depth (m) } \\
(\mathrm{m})\end{array}$ & $\begin{array}{c}\text { Mean } \\
\text { surface } \\
\text { area }\left(\mathrm{km}^{2}\right)\end{array}$ & $\begin{array}{l}\text { Retention } \\
\text { time (d) }\end{array}$ & $\begin{array}{c}\text { Trophic } \\
\text { state }\end{array}$ \\
\hline Jurumirim & $23^{\circ} 13^{\prime} \mathrm{S}, 49^{\circ} 14^{\prime} \mathrm{W}$ & 1962 & 98 & 66 & 13 & 40 & 485 & 323 & OT \\
\hline Chavantes & $23^{\circ} 7^{\prime} \mathrm{S}, 49^{\circ} 43^{\prime} \mathrm{W}$ & 1971 & 414 & 50 & 22 & 80 & 400 & 352 & OT \\
\hline Salto Grande & $22^{\circ} 54^{\prime} \mathrm{S}, 49^{\circ} 59^{\prime} \mathrm{W}$ & 1958 & 74 & 30 & 4 & 14 & 12 & 2 & ET \\
\hline Canoas II & $22^{\circ} 56^{\prime} \mathrm{S}, 50^{\circ} 15^{\prime} \mathrm{W}$ & 1999 & 72 & 33 & 9 & 19 & 23 & 5 & MT \\
\hline Canoas I & $22^{\circ} 56^{\prime} \mathrm{S}, 50^{\circ} 31^{\prime} \mathrm{W}$ & 1998 & 83 & 33 & 7 & 27 & 31 & 6 & MT \\
\hline Capivara & $22^{\circ} 39^{\prime} \mathrm{S}, 51^{\circ} 21^{\prime} \mathrm{W}$ & 1978 & 640 & 120 & 18 & 59 & 576 & 227 & MT \\
\hline Taquaruçu & $22^{\circ} 32^{\prime} \mathrm{S}, 52^{\circ} 0^{\prime} \mathrm{W}$ & 1989 & 554 & 80 & 8 & 55 & 80 & 8 & MT \\
\hline Rosana & $23^{\circ} 36^{\prime} \mathrm{S}, 52^{\circ} 52^{\prime} \mathrm{W}$ & 1987 & 372 & 116 & 9 & 34 & 220 & 20 & MT \\
\hline
\end{tabular}


et al. 2005). Organic matter concentrations were determined through carbon oxidation in $\mathrm{CO}_{2}$, reduction of chrome 6 to chrome 3 by potassium dichromate, and subsequent titration of excess iron (III) chromate (Walkley \& Black 1934). Nitrogen concentrations were measured according to the Kjeldahl method (Bremner 1996).

\section{Water quality analysis}

Water quality of the Paranapanema River reservoirs was characterized by evaluating historical series of limnological data supplemented with primary data that were collected on a large sampling campaign encompassing all 8 studied reservoirs.

Historical data on water quality for the period 2001 to 2011 were obtained by performing systematic searches in indexed databases and specialized websites. In addition, researchers and technicians from universities, research institutions, and environmental institutions that perform monitoring studies of the region's water quality were contacted, and the concessionaire responsible for the 8 hydroelectric power plants, Duke Energy Brasil, was also contacted. Raw data and documentation (records, reports, journal articles, and theses) were selected according to criteria such as data availability, description of methods used for data acquisition, geographical indication of sampling points, and sampling dates.

Samples used to extract primary data were collected from pre-determined sectors in each reservoir, and they were used to characterize the areas that had a stronger influence on the reservoirs' water quality; such areas included the main channel, main arms and margins, and areas where aquaculture enterprises were already established. Water samples were collected according to APHA et al. (2005) using a 51 Van Dorn bottle. Samples were collected from 3 depths at each point (surface, mid-water, bottom). The dissolved oxygen concentrations and water temperatures were measured in situ using a digital oximeter (YSI 550A, YSI-Xylem), and the $\mathrm{pH}$ was measured using a digital pH meter (AZ-86505, AZ Instrument). A multi-probe (Manta2 4.0, Eureka Environmental) was also used for in situ measurements and confirmation of the dissolved oxygen concentration, temperature, and $\mathrm{pH}$ and to measure the electrical conductivity and turbidity. Water transparency was measured using a Secchi disk. Collected samples were immediately cooled, placed in insulated thermal boxes, and transported to land, where they were filtered through a fiber filter (Whatman 934-AH, Sigma-Aldrich), packed, and transported to the laboratory, where samples were subjected to the following analyses to determine the relevant concentrations: total phosphorus and phosphate, total nitrogen, ammonia, nitrate and nitrite, and chlorophyll a (ASTM 1994, APHA et al. 2005).

Results from the interviews and sediment and water quality analyses were gathered in a unified database, and correlations between variables and values observed for each reservoir were compared by the nonparametric Kruskal-Wallis test. Statistical analyses were performed considering a $95 \%$ of reliability and using the software Statistica 10.0 (StatSoft).

\section{TSI calculation}

Trophic state of the studied reservoirs was analyzed according to the method of Carlson (1977) as modified by Cunha et al. (2013), and the TSI was calculated according to the following equations:

$$
\begin{gathered}
\mathrm{TSI}=\frac{2 \times\left(\mathrm{TSI}_{P}+\mathrm{TSI}_{C h l}\right)+\mathrm{TSI}_{W T}}{5} \\
\mathrm{TSI}_{P}=10 \times\left\{6-\left[\frac{1.77-(0.42 \times \ln P)}{\ln 2}\right]\right\} \\
\mathrm{TSI}_{C h l}=10 \times\left\{6-\left[\frac{0.92-(0.34 \times \ln C h l)}{\ln 2}\right]\right\} \\
\mathrm{TSI}_{W T}=10 \times\left[6-\left(\frac{\ln W T}{\ln 2}\right)\right]
\end{gathered}
$$

where TSI is the trophic state index of the water body; $\mathrm{TSI}_{P}$ is the TSI relative to the total phosphorus concentration; $P$ is the water total phosphorus concentration in $\mathrm{mg} \mathrm{m}^{-3} ; \mathrm{TSI}_{\mathrm{Chl}}$ is the TSI relative to the chlorophyll a (chl a) concentration; $\mathrm{Chl}$ is the water chl a concentration in $\mathrm{mg} \mathrm{m}^{-3} ; \mathrm{TSI}_{W T}$ is the TSI relative to water transparency; and $W T$ is the water transparency measured using a Secchi disk in $\mathrm{m}$. The results were interpreted according to the classes presented in Table 2.

\section{Water quality modeling}

Primary and secondary data were used to model the water quality of the 8 studied reservoirs using the software package MOHID (Marine Environment \& Technology Center, Portugal). The MOHID water quality module was used to simulate the temperature, dissolved oxygen, phytoplankton, organic phosphorus, inorganic phosphorus, organic nitrogen, ammonia, nitrite, and nitrate. 
Table 2. Trophic state classes with the corresponding trophic state index (TSI) and changes observed in the water bodies. Adapted from Cunha et al. (2013)

\begin{tabular}{|c|c|c|}
\hline Trophic class & TSI & Water body characteristics \\
\hline Ultra-oligotrophic & $<47$ & $\begin{array}{l}\text { Very clean water; negligible nutrient concentrations; adequate water quality for } \\
\text { different uses }\end{array}$ \\
\hline Oligotrophic & $47 \leq \mathrm{TSI}<52$ & Clean water; low nutrient concentration; no undesirable effects on water quality \\
\hline Mesotrophic & $52 \leq \mathrm{TSI}<59$ & $\begin{array}{l}\text { Water with intermediate nutrient concentrations; possible effects on water quality } \\
\text { with acceptable levels }\end{array}$ \\
\hline Eutrophic & $59 \leq \mathrm{TSI}<63$ & $\begin{array}{l}\text { Water with decreased transparency; high nutrient concentrations; undesirable } \\
\text { changes to water quality; increased algal blooms }\end{array}$ \\
\hline Supereutrophic & $63 \leq \mathrm{TSI}<67$ & $\begin{array}{l}\text { Water with low transparency; high nutrient concentration; undesirable changes to } \\
\text { water quality; frequent algal blooms }\end{array}$ \\
\hline Hypereutrophic & $\geq 67$ & $\begin{array}{l}\text { Water with high turbidity; high organic matter and nutrient concentrations; pronounced } \\
\text { decrease of water quality; intense algal blooming; fish mortality }\end{array}$ \\
\hline
\end{tabular}

The modeling process included the following stages: (1) delimitation of the calculation grid; (2) fitting of the primary data to the stratification layers; (3) definition of water flow scenarios; (4) evaluation of the inflow originating upstream and from tributary water bodies; (5) projection of hydrodynamic circulation; (6) calibration of the model; and (6) simulation of the final scenario.

Georeferenced tridimensional models were used to obtain a detailed visualization of the circulation and stratification processes of the water column that delimited the modeling units (or cells) with different water quality standards. The number of cells in the different calculation grids was determined based on the area and bathymetry of each reservoir as well as the arrangement of sampling points. The grid's horizontal resolution varied between $150 \times 150 \mathrm{~m}$ $\left(22500 \mathrm{~m}^{2}\right)$ and $50 \times 50 \mathrm{~m}\left(2500 \mathrm{~m}^{2}\right)$, depending on the reservoir area. Three or 4 vertical layers were considered for each reservoir, and they were defined according to the reservoir depth.

Georeferenced bathymetric data were obtained for all reservoirs during the primary data campaign using a digital geographic positioning system (GPS; R-130, Hemisphere GPS) and an echo sounder (SDE-28, South Surveying \& Mapping Instrument) attached to the side of a boat. The data were obtained along cross and longitudinal sections of the main channel (pre-determined), with a distance of 100 to $1000 \mathrm{~m}$ between them depending on the reservoir's area and morphology. Approximately $4000 \mathrm{~km}$ were covered along the sections over $188 \mathrm{~d}$.

The bathymetric data associated with the primary data of water quality standards for the samples collected at different depths were used to determine and characterize the water column stratification layers of each reservoir. The following vertical layers were considered: surface, mid-euphotic zone, lower euphotic zone, and bottom. In shallower areas, only 3 layers were considered, and only 1 was in the euphotic zone, i.e. surface, euphotic zone, and bottom. Because the depth distributions were different for the different reservoirs, bathymetric data were interpolated to determine the limit depths between the 3 or 4 layers considered for each studied reservoir.

For the models, constant levels and flows were defined based on the average of the historical series of each reservoir recorded between 2000 and 2010 . Based on the historical water flow data obtained for dry and rainy periods (according to information from the National Institute of Meteorology of Brazil - Instituto Nacional de Meteorologia do Brasil), 2 scenarios were simulated to predict extreme conditions at the reservoirs: high flow or critical flow. All of the collected water flow data were sorted, and values within the lowest $5 \%$ were assigned to the critical flow scenario, whereas those within the highest $5 \%$ were assigned to the high flow scenario.

Because it is a cascade reservoir system, water discharge originating from upstream reservoirs was considered to directly interfere with the water quality of downstream reservoirs. In addition to the cascade discharge, water input from tributary water bodies also interfered with the respective reservoirs, and the level of significance depended on the hydrological characteristics and flow of these tributaries. In general, most of the flow data obtained for the Paranapanema River reservoirs were restricted to this river and certain tributaries. However, for Jurumirim (the most upstream cascade reservoir), the flows of its tributaries were obtained through their 
percentage contribution to the flow recorded during the dry and rainy periods.

However, it was still necessary to consider the internal effect of water circulation and wind action in the reservoirs. These 2 factors vary significantly with the reservoir morphology (dendritic or run-of-theriver), bottom topography, and currents of the tributary water bodies. The MOHID was parameterized to detail and integrate this complex network of hydrodynamic information to simulate the interference on water quality standards among the cells of the calculation grid for each reservoir.

The water quality model was calibrated according to the mathematical parameterization of MOHID that was best fit to the real data. Relatively limited data are available on the studied reservoirs; therefore, the models were fitted to represent as accurately as possible the most common values recorded for the reservoirs (median values of the historical series and water quality primary data).

Data from the rainy period were used to calibrate the model, whereas data from the dry period were used to validate the calibrated parameterization. Model calibration focused on the parameters of highest interest in relation to the TSI calculation (nitrogen and phosphorus compounds, transparency, and chl a).

At the end of the modeling runs, individual simulations of the water quality standards were obtained for each reservoir calculation cell for the proposed scenarios. The TSI values were also determined for each cell. Because the goal of this study was to estimate the polluting potential of fish cage farming in these reservoirs, the maximum simulated values of total phosphorus and chl a under critical flow conditions were used to determine the individual TSI values.

The final results were presented as maps and used to identify different trophic states (with different colors) based on the TSI determined for the entire extension of the 8 studied reservoirs.

\section{RESULTS AND DISCUSSION}

\section{Licensing to establish aquaculture enterprises}

Fish cage farming at the Paranapanema River reservoirs has been conducted since at least 2000 . The first requests for the use of individual aquaculture areas date from 2001, and the first authorizations were granted in December 2002 (Nogueira et al. 2006). According to SINAU/MPA, the 8 artificial reservoirs located along the Paranapanema River have been responsible for $14 \%$ of the licensing demand for the use of continental aquatic environments in Brazil over the last $10 \mathrm{yr}$ (from March 2004 to May 2014), which indicates the importance of these reservoirs for the development of Brazilian aquaculture. During this period, 242 processes were filed to license aquaculture areas for fish cage farming. Capivara was the most targeted (79), followed by Rosana (50) and Chavantes (40). Seven requests were filed for Taquaruçu and 1 for Salto Grande over the past 10 yr (Table 3).

The Interministerial Normative Ruling No. 7 has determined that up to $1 \%$ of the reservoir areas can be used for aquaculture (Brazil 2005a). If all of the currently filed requests to establish aquaculture enterprises were authorized, at least $18.4 \%$ of the maximal potential for fish farm establishment at these 8 reservoirs would already be claimed, even before the installation of aquaculture parks in the region. At Canoas II, if all of the requests were granted, the occupation rate would be higher than the legal maximum limit $(122.8 \%)$. The Jurumirim reservoir has the highest expansion potential because the current demand is lower than $10 \%$ of the potentially available area (Table 4). However, the $1 \%$ occupation limit of the reservoir area provided by the legislation is not based on technical studies but on political decisions.

Of the 242 requests filed, $188(78 \%)$ were granted by the MPA, $54(22 \%)$ require revisions/changes by the interested parties, and only $1(0.4 \%)$ request was not granted. This extremely low level of rejection by the MPA has been observed throughout the entire national territory because out of 1772 requests filed,

Table 3. Requests filed with the Ministry of Fishing and Aquaculture (Ministério da Pesca e Aquicultura) for licensing of aquaculture enterprises within artificial reservoirs of the Paranapanema River and registered between March 2004 and May 2014 at the Sistema de informação das autorizações de uso das águas de domínio da União para fins de aquicultura (SINAU/MPA), the information system for permits of Brazilian water use for aquaculture purposes (Brazil 2014). Values in parentheses are the percentages of approved/rejected requests relative to those filed

\begin{tabular}{|lrccc|}
\hline Reservoir & Filed & Approved & Rejected & $\begin{array}{c}\text { Demand } \\
\text { for changes }\end{array}$ \\
\hline Jurumirim & 29 & $26(90)$ & $0(0)$ & $3(10)$ \\
Chavantes & 40 & $32(80)$ & $0(0)$ & $8(20)$ \\
Salto Grande & 1 & $1(100)$ & $0(0)$ & $0(0)$ \\
Canoas II & 20 & $16(80)$ & $1(5)$ & $3(15)$ \\
Canoas I & 16 & $11(69)$ & $0(0)$ & $5(31)$ \\
Capivara & 79 & $57(72)$ & $0(0)$ & $22(28)$ \\
Taquaruçu & 7 & $6(86)$ & $0(0)$ & $1(14)$ \\
Rosana & 50 & $39(78)$ & $0(0)$ & $11(22)$ \\
\hline
\end{tabular}


Table 4. Areas requested for the establishment of aquaculture parks in the Paranapanema River artificial reservoirs according to processes filed with the Ministry of Fishing and Aquaculture (Ministério da Pesca e Aquicultura) between March 2004 and May 2014. The maximum area allowed for aquaculture and the area required by the processes were established by the government of Brazil (Brazil 2005a, 2014)

\begin{tabular}{|c|c|c|c|c|}
\hline \multirow[t]{2}{*}{ Reservoir } & \multicolumn{4}{|c|}{ Area $\left(\mathrm{km}^{2}\right)$} \\
\hline & $\begin{array}{c}\text { Mean } \\
\text { surface }\end{array}$ & $\begin{array}{l}\text { Maximum } \\
\text { allowed for } \\
\text { aquaculture }\end{array}$ & $\begin{array}{l}\text { Required } \\
\text { by } \\
\text { processes }\end{array}$ & $\begin{array}{c}\text { Claimed } \\
(\%)\end{array}$ \\
\hline Jurumirim & 485 & 4.85 & 0.46 & 9.5 \\
\hline Chavantes & 400 & 4.00 & 0.53 & 13.2 \\
\hline Salto Grande & 12 & 0.12 & 0.02 & 13.7 \\
\hline Canoas II & 23 & 0.23 & 0.28 & 122.8 \\
\hline Canoas I & 31 & 0.31 & 0.26 & 83.1 \\
\hline Capivara & 576 & 5.76 & 0.82 & 14.2 \\
\hline Taquaruçu & 80 & 0.80 & 0.10 & 12.6 \\
\hline Rosana & 220 & 2.20 & 0.90 & 41.0 \\
\hline
\end{tabular}

only $22(1.2 \%)$ were rejected; this situation indicates an evident lack of rigor or even negligence by the authorities when evaluating the requests, because many of the areas requested for aquaculture are known to be unfit for the establishment of aquaculture enterprises. However, after requests are approved by the MPA, the interested parties must still obtain environmental permits; therefore, in $10 \mathrm{yr}$, only $42(18 \%)$ processes have been granted full authorization for water use for aquaculture purposes at the Paranapanema River reservoirs.

\section{Current situation of fish farming in the studied region}

The parties responsible for 27 out of 37 fish cage farms located and identified at the 8 studied reservoirs were willing to answer the proposed questionnaire, and the answers are summarized in Table 5. Fish cage farming was being performed in 7 of the 8 reservoirs, albeit at a small scale, and was absent in Salto Grande.

In all of the studied fish farms, the farmers acquire fry from other producers and then raise and fatten the fish until they reach slaughter weight or resale weight for sport fishing (between 500 and $800 \mathrm{~g}$ ). Production is usually targeted at distributors $(31 \%)$, fisherman (sport fishing; 28\%), and several cold storage plants located in the region $(41 \%)$. All interviewed producers stated that they produce Nile tilapia Oreochromis niloticus L., and this preference is related to factors such as short growth cycle, good mar-

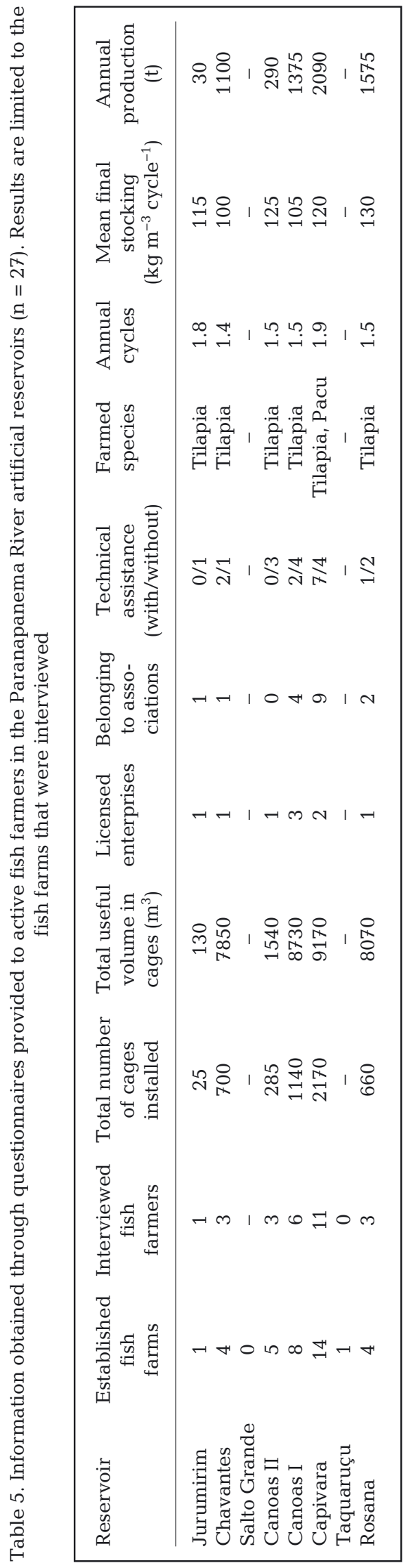


ket acceptance, adequate adaptation to cage farming conditions, and satisfactory feed conversion, which results in lower production costs compared with other species used in this type of farming system (Furlaneto et al. 2006). Of the fish with the potential for cage farming, the Nile tilapia has become the most widely grown species in Brazil in recent decades and represents approximately $40 \%$ of the production volume of domestic aquaculture (Marengoni 2006).

The questionnaires also attempted to ascertain the level of experience of the fish farmers and revealed that fish farming at the Paranapanema River reservoirs is a fairly recent activity; $70 \%$ of the producers had only been farming for 1 to $10 \mathrm{yr}$. However, $63 \%$ of the interviewees had less than $5 \mathrm{yr}$ of experience with fish cage farming, and $47 \%$ stated that they had previous experience with fish farming in the region in ponds.

Although technical assistance is fundamental to increase the productivity and commercial value of aquaculture production (da Silva 2001) and optimize the production practices and overall supply chain, only 12 (44\%) producers stated they had access to any type of technical assistance. This lack of assistance represents an important bottleneck for the eventual expansion of fish farming in the region because small fish farmers have little capital and cannot easily procure credit. Additionally, the government public service is not currently in place to provide technical assistance and rural extension that are sufficiently structured to meet current or future demands.

Technical assistance and rural extension are fundamental links between fish farmers and government institutions, technical and technological research institutions, and the market (Kumar 1999, Edwards et al. 2002). Without specialized technical assistance, the risk of committing technical errors and impacting the environment is increased and the chances of successfully implementing fish farms are decreased.

However, $63 \%$ of the producers stated they are connected to some type of rural producer association, with most formed by fish farmers. The main goal of these organizations should be to guide rural producers in cultivation practices, disseminate technology and market information, and defend the interests of their members before the regulatory agencies (FAO 2011). In practice, however, we noted in this study that the majority of these associations do not act effectively and only represent a legal vehicle for obtaining tax advantages for some producers.

According to the data presented by the SINAU/ MPA, 42 entrepreneurs are legally authorized to operate fish farms in the Paranapanema River artifi- cial reservoirs, which is in accordance with the 37 farms identified by the present field survey. However, according to the producers' answers to the questionnaires, only a third of the active enterprises are legally authorized to operate. Therefore, the 42 enterprises that obtained licenses are not represented by the 37 enterprises operating in the reservoirs.

This result is consistent with survey data from other regions of Brazil and supports the irregular operations on public waters in Brazil. Dotti et al. (2012) estimated that at least $70 \%$ of the small fish farmers in Brazilian public waters act informally, and this percentage is similar to what was observed in the present study. According to the interviewed producers, the main reasons behind the informality of their enterprises are a lack of knowledge of current legislation and/or bureaucratic procedures, difficulty in elaborating technical projects, and a feeling of impunity resulting from the inefficient control of illegal enterprises by public agencies.

\section{Prospects for expanding fish farming in the studied region}

Two-thirds of the interviewed fish farmers were interested in expanding their production through the installation of additional cages. The remaining producers intended to determine means of increasing productivity gains and profitability, even without increasing the total farmed area.

According to the fish farmers, the construction of new slaughter and processing units at the north region of Paraná is important for the development of fish farming in the region. To local markets and to the main cities in the region, these units would offer a standardized industrial fish product suitable for domestic consumption, thereby increasing the local demand for fish and facilitating marketing the production.

The data from SINAU/MPA were used to obtain a short- to medium-term growth estimate of fish production in the Paranapanema River reservoirs, even without the establishment of aquaculture parks (Table 6). If only the processes that have already been filed were established, the total production of the 8 reservoirs could increase over $250 \%$ (from 8810 to $23615 \mathrm{t} \mathrm{yr}^{-1}$ ). This estimate is in accordance with growth expectations for the domestic tilapia production, which has been predicted to triple over the next 20 yr (Capobianco 2013). However, to guarantee the economic, environmental, and social sustainability of this growth, policies that support the development of 
Table 6. Estimate of increased fish cage farming in Paranapanema River reservoirs based on the current production and growth potential and relative to the new aquaculture parks licensed by the SINAU/MPA. Data adapted from Brazil (2014). Estimated production of the established parks was calculated from data obtained from the interviewed producers. Relative volume in cages was estimated based on $10 \%$ of the useful area of the parks occupied by $4 \mathrm{~m}^{2}$ cages (standard cages are $6 \mathrm{~m}^{3}$ ). Estimated production of new parks was based on a mean final stocking of $125 \mathrm{~kg} \mathrm{~m}^{-3}$ production cycle $^{-1}$ in $1.5 \mathrm{cycles}_{\mathrm{yr}}^{-1}$

\begin{tabular}{|c|c|c|c|c|c|c|}
\hline Reservoir & $\begin{array}{l}\text { Production of } \\
\text { the } 27 \text { inter- } \\
\text { viewees }\left(\mathrm{t} \mathrm{yr}^{-1}\right)\end{array}$ & 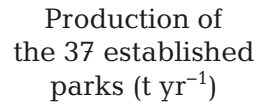 & $\begin{array}{l}\text { Area of the } \\
\text { new licensed } \\
\text { parks (ha) }\end{array}$ & $\begin{array}{c}\text { Relative } \\
\text { volume in } \\
\text { cages }\left(\mathrm{m}^{3}\right)\end{array}$ & $\begin{array}{l}\text { Production of } \\
\text { new parks } \\
\left(\mathrm{t} \mathrm{yr}^{-1}\right)\end{array}$ & $\begin{array}{l}\text { Current pro- } \\
\text { duction + new } \\
\text { parks }\left(\mathrm{t} \mathrm{yr}^{-1}\right)\end{array}$ \\
\hline Jurumirim & 30 & 30 & 8.7 & 12960 & 2430 & 2460 \\
\hline Chavantes & 1100 & 1470 & 12.7 & 18945 & 3550 & 5020 \\
\hline Salto Grande & 0 & 0 & 0.0 & 0 & 0 & 0 \\
\hline Canoas II & 290 & 480 & 5.2 & 7815 & 1465 & 1945 \\
\hline Canoas I & 1375 & 1830 & 1.1 & 1575 & 295 & 2125 \\
\hline Capivara & 2090 & 2660 & 7.5 & 11175 & 2095 & 4755 \\
\hline Taquaruçu & 0 & $240^{\mathrm{a}}$ & 1.5 & 2145 & 400 & 640 \\
\hline Rosana & 1575 & 2100 & 16.3 & 24360 & 4570 & 6670 \\
\hline ALL & 6460 & 8810 & 52.7 & 78975 & 14805 & 23615 \\
\hline
\end{tabular}

the supply chain as a whole should be developed to increase the fish supply processed by the industry and (more importantly) assimilated by the market (da Silva 2005).

Regardless of the socio-economic and environmental issues, the maximum production potential of aquaculture enterprises is still limited by legislation on the use of Brazilian water bodies for aquaculture purposes, which is set at $1 \%$ of the mean reservoir area (Brazil 2005a). The total area of the 8 reservoirs is $1827 \mathrm{~km}^{2}$, and if the same calculation criteria from the estimates in Table 5 are applied, then the production from fish cage farming would be above $500000 \mathrm{t} \mathrm{yr}^{-1}$. Thus, even if the full growth that is estimated for the short to medium term is realized, only $5 \%$ of the maximal production potential would be used. However, the full production potential could be limited by environmental and market capacity, even without considering the need for investments to the supply chain infrastructure.

\section{Characterization of bottom sediments}

Sediment organic matter, phosphorus, and nitrogen concentrations at different points along the reservoirs were used as indicators of the current level of environmental impact caused by the fish farms already operating within the Paranapanema River reservoirs and for the production model practiced in the region. No significant differences $(p>0.05)$ in bottom sediment organic matter, nitrogen, and phosphorus concentrations were observed between areas with and without fish farming. Therefore, significant changes to the sediment composition of the areas in which the fish farms are currently operating in the Paranapanema River reservoirs were not observed (Table 7).

The solid residue generated by fish cage farming is rich in organic matter, nitrogen, and phosphorus and tends to sediment and deposit in the reservoir bed close to the fish farming structures, where it can

Table 7. Mean \pm SE nutrient concentrations in the bottom sediment of the Paranapanema River artificial reservoirs $(n=50)$. Values followed by different letters in the same column are significantly different $(\mathrm{p}<0.05$, Kruskal-Wallis test)

\begin{tabular}{|lcccc|}
\hline Reservoir & $\mathrm{n}$ & $\begin{array}{c}\text { Organic } \\
\text { matter }(\%)\end{array}$ & $\begin{array}{c}\text { Nitrogen } \\
\left(\mathrm{g} \mathrm{dm}^{-3}\right)\end{array}$ & $\begin{array}{c}\text { Phosphorus } \\
\left(\mathrm{mg} \mathrm{kg}^{-1}\right)\end{array}$ \\
\hline Jurumirim & 4 & $7.34 \pm 0.70^{\mathrm{a}}$ & $3.67 \pm 0.35^{\mathrm{a}}$ & $6.25 \pm 2.39^{\mathrm{b}}$ \\
Chavantes & 11 & $2.37 \pm 0.44^{\mathrm{b}}$ & $1.18 \pm 0.22^{\mathrm{b}}$ & $3.24 \pm 1.50^{\mathrm{bc}}$ \\
Salto Grande & 2 & $2.92 \pm 1.00^{\mathrm{b}}$ & $1.46 \pm 0.50)^{\mathrm{b}}$ & $1.33 \pm 3.38^{\mathrm{c}}$ \\
Canoas II & 5 & $3.35 \pm 0.64^{\mathrm{b}}$ & $1.68 \pm 0.32^{\mathrm{b}}$ & $3.28 \pm 2.18^{\mathrm{bc}}$ \\
Canoas I & 8 & $2.97 \pm 0.50^{\mathrm{b}}$ & $1.48 \pm 0.25^{\mathrm{b}}$ & $3.81 \pm 1.69^{\mathrm{bc}}$ \\
Capivara & 14 & $2.10 \pm 0.42^{\mathrm{b}}$ & $1.05 \pm 0.21^{\mathrm{b}}$ & $9.38 \pm 1.44^{\mathrm{ab}}$ \\
Taquaruçu & 2 & $1.56 \pm 1.00^{\mathrm{b}}$ & $0.78 \pm 0.50^{\mathrm{b}}$ & $15.48 \pm 3.38^{\mathrm{a}}$ \\
Rosana & 4 & $2.62 \pm 0.81^{\mathrm{b}}$ & $1.30 \pm 0.41^{\mathrm{b}}$ & $5.50 \pm 2.76^{\mathrm{b}}$ \\
Areas under fish farms & 17 & $2.82 \pm 1.11$ & $1.41 \pm 0.55$ & $4.31 \pm 2.39$ \\
Remaining areas & 33 & $2.92 \pm 2.21$ & $1.46 \pm 1.11$ & $7.38 \pm 4.38$ \\
TOTAL & 50 & $2.89 \pm 1.90$ & $1.44 \pm 0.95$ & $6.34 \pm 3.29$ \\
Probability & & & & \\
Reservoirs & & 0.008 & $<0.001$ & 0.016 \\
Fish farms & & 0.273 & 0.438 & 0.675 \\
Reservoir $\times$ Fish farms & & 0.698 & 0.174 & 0.027 \\
\hline
\end{tabular}


cause significant environmental changes (Grey et al. 2004). Gondwe et al. (2011b) observed that sediments were dispersed in locations with current speeds higher than $9.3 \mathrm{~cm} \mathrm{~s}^{-1}$, thus minimizing and even preventing environmental impacts. This result indicates the importance of choosing areas with good water circulation for cage installation. Nevertheless, factors such as poor nutritional quality of the feed or inadequate feeding practices and stocking densities may increase nutrient losses and cause increased local sedimentation rates (Gondwe et al. 2011a).

The current results are likely related to the incipient level of fish farming in the Paranapanema River reservoirs. This activity has developed over less than 5 yr primarily by small producers, and there has been a low input of nutrient loads to the sediment at the farming areas. Troell \& Berg (1997) compared carbon, nitrogen, and phosphorus concentrations in the bottom sediment of Lake Kariba, Zimbabwe, before and after the establishment of small $\left(<10 \mathrm{t}\right.$ fish ha ${ }^{-1}$ $\mathrm{yr}^{-1}$ ) and large ( $>20 \mathrm{t}$ fish $\left.\mathrm{ha}^{-1} \mathrm{yr}^{-1}\right)$ fish farms dedicated to cage farming Nile tilapia and only observed significant changes for large farms.

Tlusty et al. (2000) observed that factors linked to cultivation practices, such as feeding and stocking density, as well as the hydrodynamic characteristics of the site where the fish farms were established, were more relevant than the biomass of produced fish. In the present case, the choice of fish farm location was not based on environmental or even legal criteria, as expected, but on purely operational reasons, such as ease of access, location of roadways for production transport or closeness to private areas belonging to the fish farm owners. Therefore, the results of the present study do not indicate whether environmental impacts will occur at a local scale, even if there is no increase in current production levels. This result could be explained by the low technical level and lack of specialized assistance to the fish farms. In addition, the current farming systems are expected to evolve from small nonmechanized farms into large mechanized production cages in response to the potential commercial success of the activity.

However, knowledge of the standard water quality patterns is fundamental for the success of enterprises dedicated to producing aquatic organisms, because water quality is important for the survival and zootechnical performance of the cultivated species. Moreover, the environment's capacity for receiving and processing effluents originating from aquaculture enterprises must be evaluated prior to allowing significant changes to these standards (Boyd \& Tucker 1998).

\section{Water quality characterization and modeling}

The water quality standards of the Paranapanema River artificial reservoirs derived from historical data are presented in Tables $8 \& 9$.

The mean water temperatures were between 21 and $25^{\circ} \mathrm{C}$ and below $29.9^{\circ} \mathrm{C}$, which is the temperature that Qiang et al. (2012) indicated is ideal for the zootechnical performance of Nile tilapia, the main species cultivated in the studied reservoirs. However, the recorded temperatures are still within the limits recommended by Atwood et al. (2003) for the cultivation of this species. Even when considering the surface temperature measured in water samples collected at depths of up to $2.5 \mathrm{~m}$, which is the portion of the water column with direct influence on fish farming cages, the water temperature was not higher than $28^{\circ} \mathrm{C}$. Therefore, although the production of this spe-

Table 8. Mean \pm SE water physico-chemical characteristics of the Paranapanema River artificial reservoirs according to historical data. Mean temperature was measured for water samples collected at any depth, whereas mean surface temperature was measured at depths up to $2.5 \mathrm{~m}$

\begin{tabular}{|lcccccccc|}
\hline Reservoir & $\mathrm{n}$ & $\begin{array}{c}\text { Temperature } \\
\left({ }^{\circ} \mathrm{C}\right)\end{array}$ & $\begin{array}{c}\text { Surface } \\
\text { temperature } \\
\left({ }^{\circ} \mathrm{C}\right)\end{array}$ & $\begin{array}{c}\text { Electrical } \\
\mathrm{conductivity} \\
\left(\mu \mathrm{S} \mathrm{cm}^{-1}\right)\end{array}$ & $\begin{array}{c}\text { Dissolved } \mathrm{O}_{2} \\
\left(\mathrm{~g} \mathrm{~m}^{-3}\right)\end{array}$ & $\mathrm{pH}$ & $\begin{array}{c}\text { Turbidity } \\
(\mathrm{NTU})\end{array}$ & $\begin{array}{c}\text { Transparency } \\
(\mathrm{m})\end{array}$ \\
\hline Jurumirim & 505 & $21.13 \pm 1.79$ & $25.52 \pm 1.02$ & $50.30 \pm 9.52$ & $7.05 \pm 1.14$ & $7.19 \pm 1.07$ & $10.88 \pm 4.11$ & $1.49 \pm 0.93$ \\
Chavantes & 781 & $21.56 \pm 1.86$ & $24.26 \pm 1.79$ & $56.09 \pm 6.58$ & $6.35 \pm 1.33$ & $7.11 \pm 0.28$ & $12.80 \pm 5.80$ & $2.21 \pm 1.06$ \\
Salto Grande & 180 & $20.39 \pm 1.51$ & $23.12 \pm 0.58$ & $59.24 \pm 7.78$ & $7.57 \pm 1.18$ & $7.09 \pm 0.31$ & $20.02 \pm 4.47$ & $2.02 \pm 0.94$ \\
Canoas II & 225 & $20.80 \pm 1.09$ & $23.45 \pm 0.27$ & $63.40 \pm 14.12$ & $7.01 \pm 1.19$ & $7.03 \pm 0.29$ & $45.43 \pm 5.78$ & $2.05 \pm 0.39$ \\
Canoas I & 238 & $20.17 \pm 1.36$ & $22.81 \pm 0.57$ & $55.62 \pm 6.39$ & $7.17 \pm 1.36$ & $7.04 \pm 0.36$ & $10.43 \pm 1.50$ & $2.69 \pm 0.44$ \\
Capivara & 314 & $20.03 \pm 1.31$ & $21.64 \pm 1.29$ & $62.18 \pm 8.47$ & $7.60 \pm 0.99$ & $7.39 \pm 0.36$ & $12.33 \pm 1.47$ & $2.14 \pm 0.97$ \\
Taquaruçu & 795 & $20.16 \pm 0.93$ & $23.07 \pm 0.67$ & $57.97 \pm 9.76$ & $7.71 \pm 0.90$ & $7.33 \pm 0.35$ & $11.50 \pm 1.26$ & $1.99 \pm 0.56$ \\
Rosana & 130 & $22.29 \pm 0.93$ & $25.76 \pm 1.24$ & $51.58 \pm 22.38$ & $7.30 \pm 0.98$ & $6.91 \pm 0.53$ & $8.85 \pm 2.35$ & $2.08 \pm 0.60$ \\
\hline
\end{tabular}


Table 9. Mean \pm SE water quality standards of the Paranapanema River artificial reservoirs according to historical data

\begin{tabular}{|c|c|c|c|c|c|c|c|c|}
\hline Reservoir & $\mathrm{n}$ & $\begin{array}{l}\text { Chlorophyll a } \\
\quad\left(\mathrm{mg} \mathrm{m}^{-3}\right)\end{array}$ & $\begin{array}{c}\text { Total } \\
\text { phosphorus } \\
\left(\mathrm{mg} \mathrm{m}^{-3}\right)\end{array}$ & $\begin{array}{l}\text { Orthophosphate } \\
\qquad\left(\mathrm{mg} \mathrm{m}^{-3}\right)\end{array}$ & $\begin{array}{l}\text { Nitrate } \\
\left(\mathrm{g} \mathrm{m}^{-3}\right)\end{array}$ & $\begin{array}{l}\text { Nitrite } \\
\left(\mathrm{mg} \mathrm{m}^{-3}\right)\end{array}$ & $\begin{array}{c}\text { Ammonia } \\
\left(\mathrm{g} \mathrm{m}^{-3}\right)\end{array}$ & $\begin{array}{c}\text { Total } \\
\text { nitrogen } \\
\left(\mathrm{g} \mathrm{m}^{-3}\right)\end{array}$ \\
\hline Jurumirim & 505 & $3.12 \pm 2.62$ & $37.75 \pm 12.59$ & $12.16 \pm 1.85$ & $0.27 \pm 0.15$ & $4.07 \pm 1.94$ & $0.10 \pm 0.06$ & $0.91 \pm 0.18$ \\
\hline Chavantes & 781 & $1.22 \pm 1.32$ & $31.36 \pm 7.85$ & $13.10 \pm 4.08$ & $0.26 \pm 0.06$ & $10.34 \pm 1.53$ & $0.07 \pm 0.01$ & $0.80 \pm 0.22$ \\
\hline Salto Grande & 180 & $0.70 \pm 0.50$ & $48.67 \pm 9.84$ & $16.15 \pm 1.82$ & $0.35 \pm 0.07$ & $1.55 \pm 0.23$ & $0.18 \pm 0.06$ & $0.78 \pm 0.11$ \\
\hline Canoas II & 225 & $1.88 \pm 2.42$ & $40.45 \pm 15.65$ & $16.57 \pm 2.19$ & $0.30 \pm 0.12$ & $2.61 \pm 0.11$ & $0.24 \pm 0.04$ & $0.65 \pm 0.13$ \\
\hline Canoas I & 238 & $2.44 \pm 5.79$ & $38.33 \pm 8.84$ & $15.12 \pm 1.87$ & $0.39 \pm 0.15$ & $2.20 \pm 0.80$ & $0.24 \pm 0.03$ & $0.81 \pm 0.08$ \\
\hline Capivara & 314 & $0.73 \pm 0.38$ & $33.18 \pm 8.25$ & $17.99 \pm 1.91$ & $0.20 \pm 0.13$ & $4.63 \pm 1.98$ & $0.17 \pm 0.07$ & $0.65 \pm 0.13$ \\
\hline Taquaruçu & 795 & $1.10 \pm 0.62$ & $35.42 \pm 8.56$ & $17.93 \pm 2.13$ & $0.42 \pm 0.19$ & $2.10 \pm 1.04$ & $0.24 \pm 0.06$ & $0.70 \pm 0.12$ \\
\hline Rosana & 130 & $3.42 \pm 2.11$ & $30.71 \pm 10.76$ & $10.84 \pm 1.82$ & $0.23 \pm 0.07$ & $9.91 \pm 1.29$ & $0.20 \pm 0.06$ & $0.74 \pm 0.27$ \\
\hline
\end{tabular}

cies is technically viable at the Paranapanema River reservoirs, this region does not display the highest temperature potential for tilapia farming in Brazil.

The concentrations of dissolved oxygen, nitrogen compounds, and chl a and physical characteristics, including electrical conductivity, transparency, and $\mathrm{pH}$, classify the Paranapanema River artificial reservoirs as adequate for aquaculture according to the standards established by the Brazilian legislation for different water uses (Brazil 2005b). However, phosphorus concentrations were higher than the legislated maximal limit in all of the reservoirs (up to $30 \mathrm{mg} \mathrm{m}^{-3}$ for lentic environments and up to $50 \mathrm{mg}$ $\mathrm{m}^{-3}$ for intermediate environments with residence times between 2 and $40 \mathrm{~d}$ and direct tributaries with lentic environments). Although phosphorus concentrations are not directly limiting for the survival and performance of the farmed fish, increased phosphorus in aquatic ecosystems is considered the main cause for increased primary productivity and phytoplankton biomass (Harper 1992, Azim et al. 2004).

The TSI values in the studied reservoirs calculated from historical and primary data varied between 50 and 54, classifying the trophic state as oligotrophic $(\mathrm{TSI}<52)$ and mesotrophic (TSI > 52; Table 10). However, most of the values were close to the limit between the 2 categories, and all values could be included in either category if only the higher or lower limits of the standard deviations were considered. This result is consistent with recent studies performed in these reservoirs by Pagioro et al. (2005) and Nogueira et al. (2006), who also classified the trophic state as oligo-mesotrophic, with eutrophication occurring in reservoir arms at certain times of the year.

Variation of the TSI is strongly dependent on phosphorus loads entering the aquatic environment because of the importance of phosphorus concentrations for the TSI calculations and phytoplankton biomass increase; such increases are indicated by chl a concentrations and result in decreased transparency, which are 2 of the variables considered in determining the TSI (Sulis et al. 2011). However, other factors may also be associated with changes in trophic state, such as stratification, mean depth, retention time, trophic interactions, surface area, and depth of the water mixing zone (Reynolds et al. 2002). The impor-

Table 10. Trophic state classification of the Paranapanema River artificial reservoirs based on the trophic state index (TSI; see Table 2) and calculated using water quality parameters from historical and primary data. Trophic state classification was determined using the mean of the calculated values based on historical and primary data and by comparing the results with the classification proposed by Cunha et al.

(2013). Values are means \pm SE

\begin{tabular}{|c|c|c|c|c|c|c|c|c|c|}
\hline \multirow[t]{2}{*}{ Reservoirs } & \multicolumn{2}{|c|}{ Transparency (m) } & \multicolumn{2}{|c|}{ Total phosphorus $\left(\mathrm{mg} \mathrm{m}^{-3}\right)$} & \multicolumn{2}{|c|}{ Chlorophyll a $\left(\mathrm{mg} \mathrm{m}^{-3}\right)$} & \multicolumn{2}{|c|}{ TSI } & \multirow{2}{*}{$\begin{array}{l}\text { Trophic } \\
\text { state }\end{array}$} \\
\hline & Primary & Historical & Primary & Historical & Primary & Historical & Primary & Historical & \\
\hline Jurumirim & $2.93 \pm 0.21$ & $1.49 \pm 0.93$ & $37.51 \pm 4.21$ & $37.75 \pm 3.26$ & $3.13 \pm 0.34$ & $3.12 \pm 2.62$ & $51.80 \pm 5.27$ & $53.75 \pm 5.09$ & Mesotrophic \\
\hline Chavantes & $2.97 \pm 0.79$ & $2.21 \pm 1.06$ & $40.13 \pm 4.48$ & $31.36 \pm 3.78$ & $1.30 \pm 0.20$ & $1.22 \pm 1.32$ & $50.59 \pm 4.82$ & $50.95 \pm 4.98$ & Oligotrophic \\
\hline Salto Grande & $2.11 \pm 1.15$ & $2.02 \pm 0.94$ & $36.04 \pm 6.09$ & $48.67 \pm 4.98$ & $0.73 \pm 0.15$ & $0.70 \pm 0.50$ & $50.56 \pm 4.72$ & $51.12 \pm 4.92$ & Oligotrophic \\
\hline Canoas II & $1.98 \pm 0.75$ & $2.05 \pm 0.39$ & $45.68 \pm 5.41$ & $40.45 \pm 3.57$ & $1.88 \pm 0.45$ & $1.88 \pm 2.42$ & $52.51 \pm 4.98$ & $52.21 \pm 5.35$ & Mesotrophic \\
\hline Canoas I & $1.46 \pm 0.51$ & $2.69 \pm 0.44$ & $42.86 \pm 3.35$ & $38.33 \pm 2.88$ & $3.85 \pm 1.08$ & $2.44 \pm 5.79$ & $54.32 \pm 5.14$ & $51.72 \pm 5.41$ & Mesotrophic \\
\hline Capivara & $2.35 \pm 0.57$ & $2.14 \pm 0.97$ & $37.94 \pm 2.03$ & $33.18 \pm 2.83$ & $0.74 \pm 0.04$ & $0.73 \pm 0.38$ & $50.37 \pm 4.54$ & $50.40 \pm 4.78$ & Oligotrophic \\
\hline Taquaruçu & $2.85 \pm 0.79$ & $1.99 \pm 0.56$ & $37.88 \pm 2.66$ & $35.42 \pm 1.86$ & $1.10 \pm 0.08$ & $1.10 \pm 0.62$ & $50.38 \pm 4.60$ & $51.30 \pm 4.94$ & Oligotrophic \\
\hline Rosana & $2.32 \pm 0.27$ & $2.08 \pm 0.6$ & $34.71 \pm 3.57$ & $30.71 \pm 2.08$ & $3.06 \pm 0.46$ & $3.42 \pm 2.11$ & $52.32 \pm 5.21$ & $52.60 \pm 5.12$ & Mesotrophic \\
\hline
\end{tabular}


tance of the temporal variation in phytoplankton biomass should be noted because although this importance is implicitly accepted, the efforts of measuring and understanding this variability have been concentrated in time intervals of 1 yr or less (Jassby et al. 2002).

The results of modeling maximal TSI values calculated from critical hydrodynamic conditions and maximal values of phosphorus and chlorophyll concentrations for the entire extension of the 8 Paranapanema River artificial reservoirs in this study are presented in Fig. 2. The use of models allowed a better understanding of the reservoir dynamics, and point data can be extrapolated for the entire area of interest for aquaculture. Because the results of the model exhibited a good fit to the available data (reservoir level and water quality), it can be concluded that the model can be used to accurately simulate current and future hypothetical scenarios.

In general, the model showed that the reservoirs are predominantly mesotrophic. However, certain reservoirs exhibited eutrophic, supereutrophic, and even hypereutrophic areas in some cases. As a rule, more critical areas are located in reservoir arms in regions with poor water circulation and/or low depth. This finding is particularly relevant because most of the current aquaculture enterprises in the Paranapanema River reservoirs are established in protected regions with lower water circulation in the reservoir arms.

The current eutrophic areas only represent approximately $1 \%$ of the reservoir area except for in Jurumirim, where they represent approximately $5 \%$ of the total reservoir extension. This condition indicates an environmental risk caused by the different anthropic activities under development at the Paranapanema River Basin, which can compromise the viability of the active enterprises.

Fish cage farming in the Paranapanema River artificial reservoirs is still low considering its natural and legal potential. This activity is primarily developed by small producers who mostly operate illegally, with a low technical level, limited access to technical assistance, low levels of social organization, and difficulty marketing their products. However, the federal program to incentivize aquaculture should considerably increase the number of enterprises in the region over the medium term.

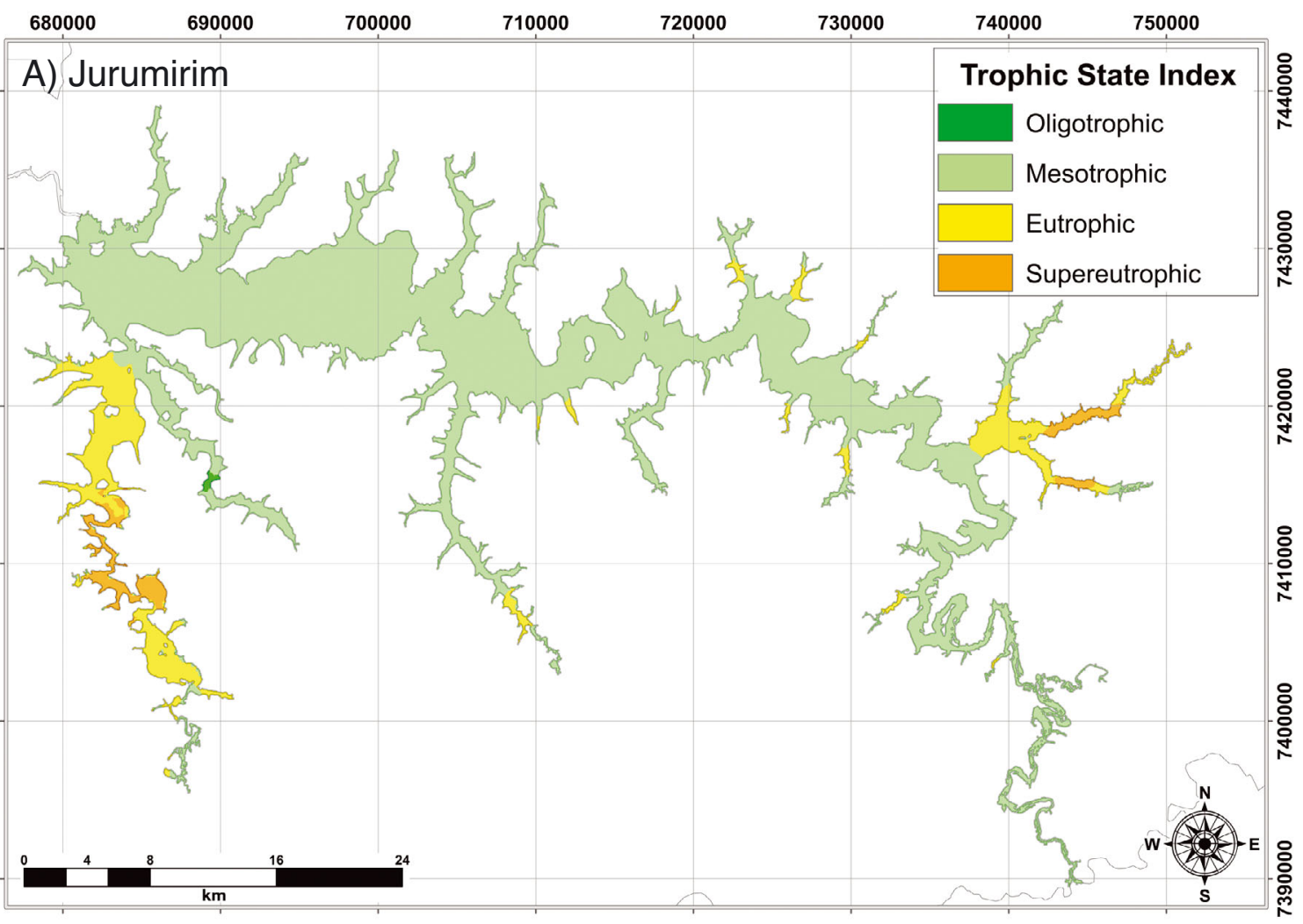

Fig. 2. Trophic state index under critical hydrodynamic conditions in the 8 large artificial reservoirs, Paranapanema River Basin, Brazil: (A) Jurumirim, (B) Chavantes, (C) Salto Grande, (D) Canoas II, (E) Canoas I, (F) Capivara, (G) Taquaruçu and (H) Rosana 

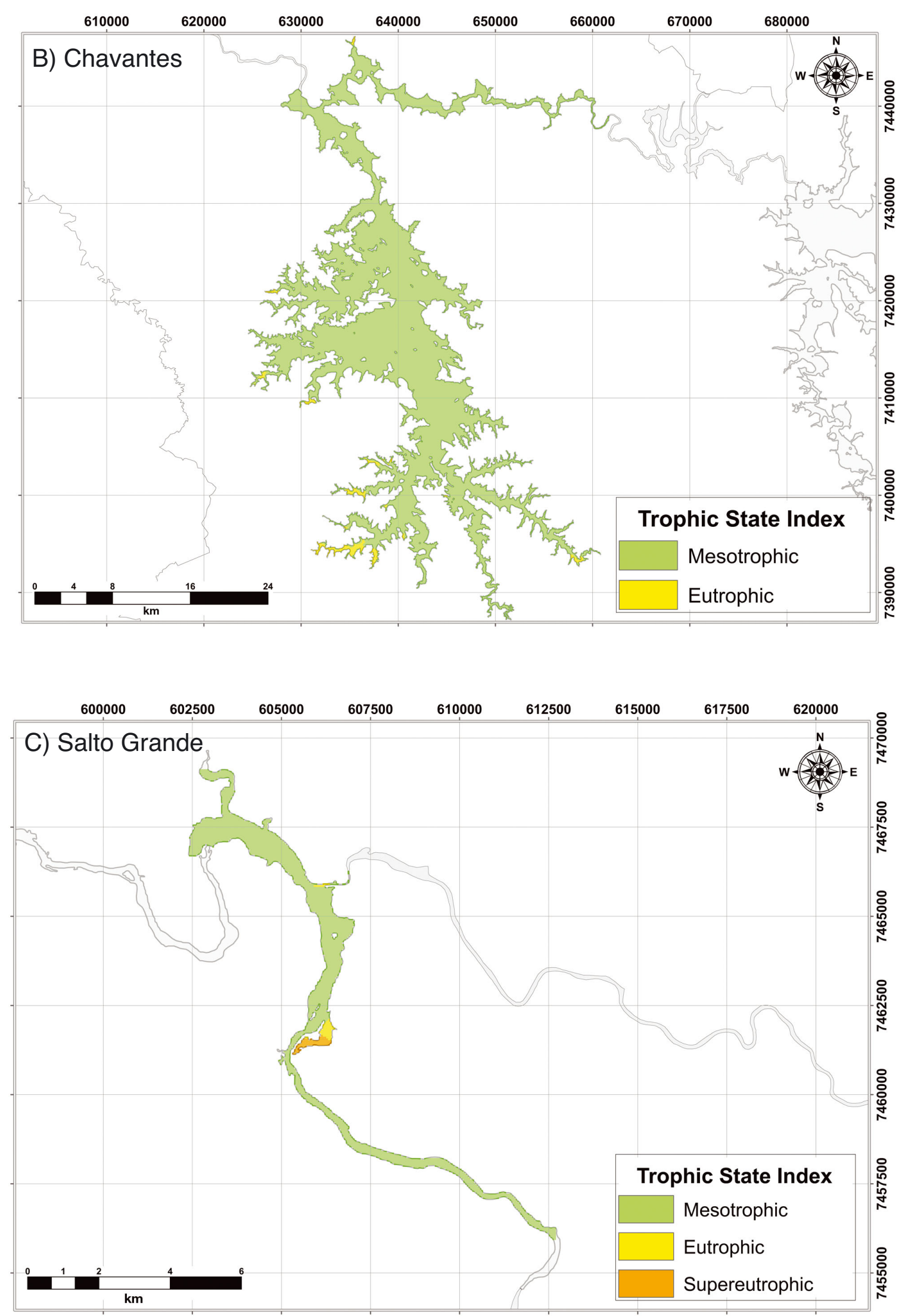

Fig. 2 (continued) 

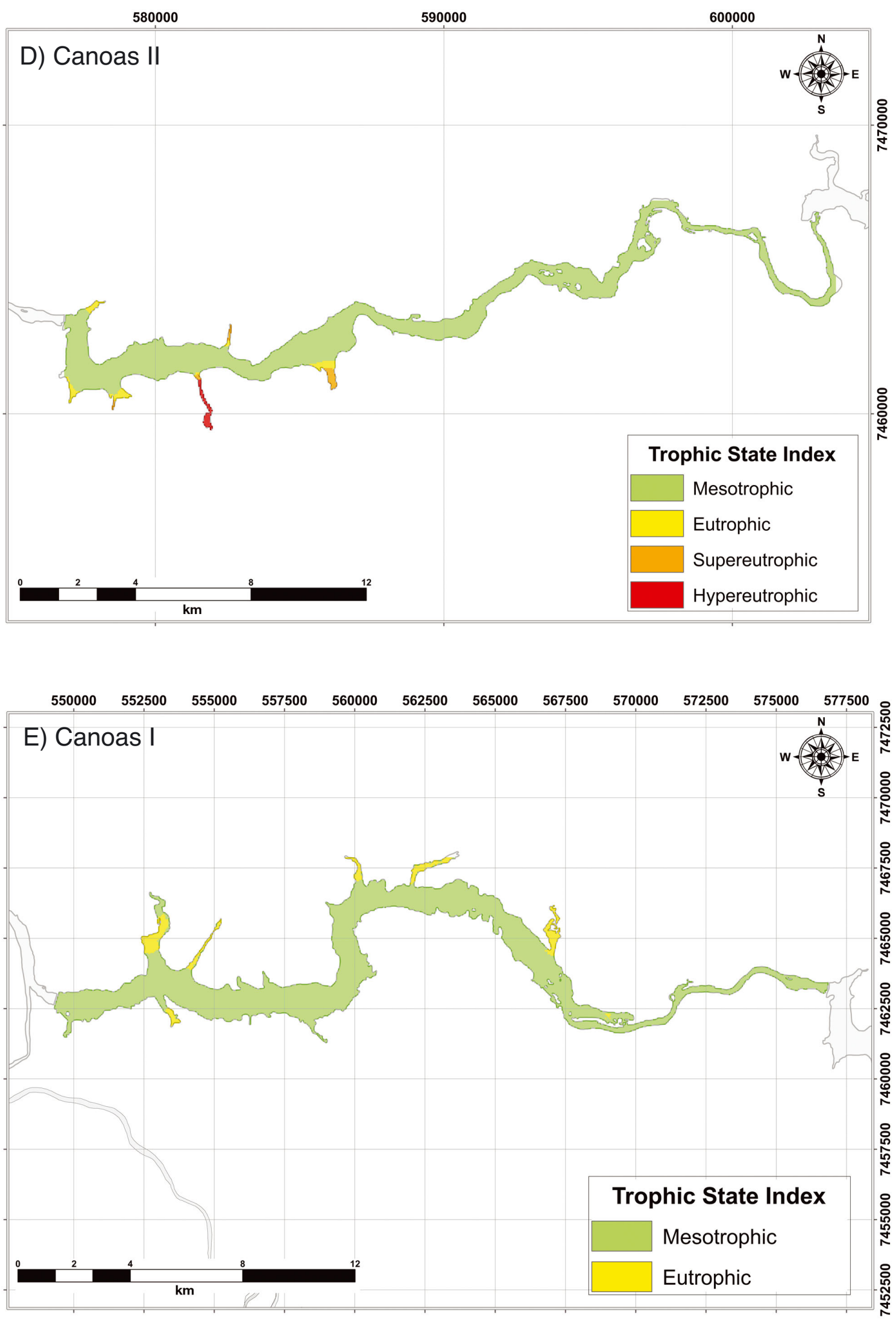

Fig. 2 (continued) 

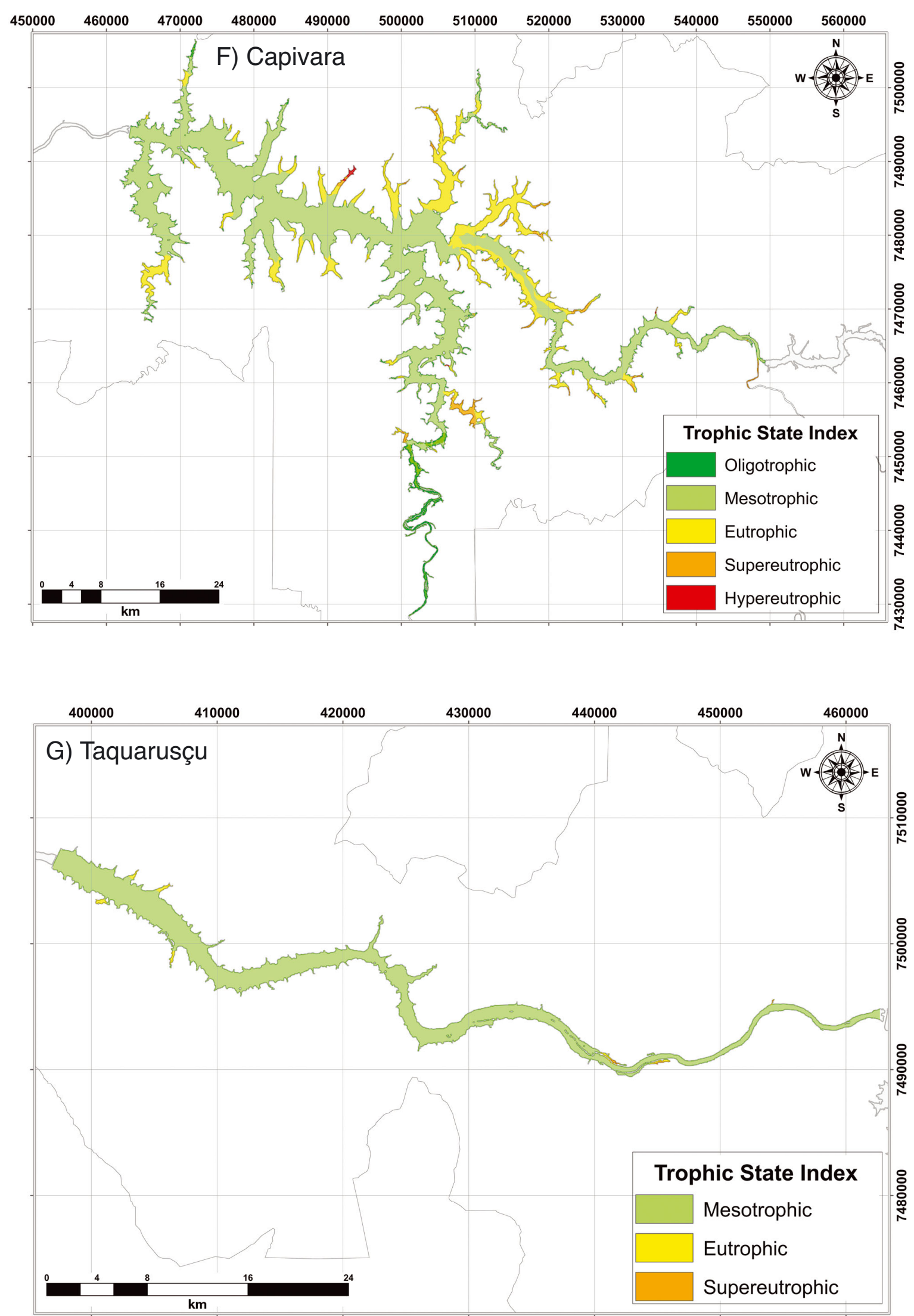

Fig. 2 (continued) 


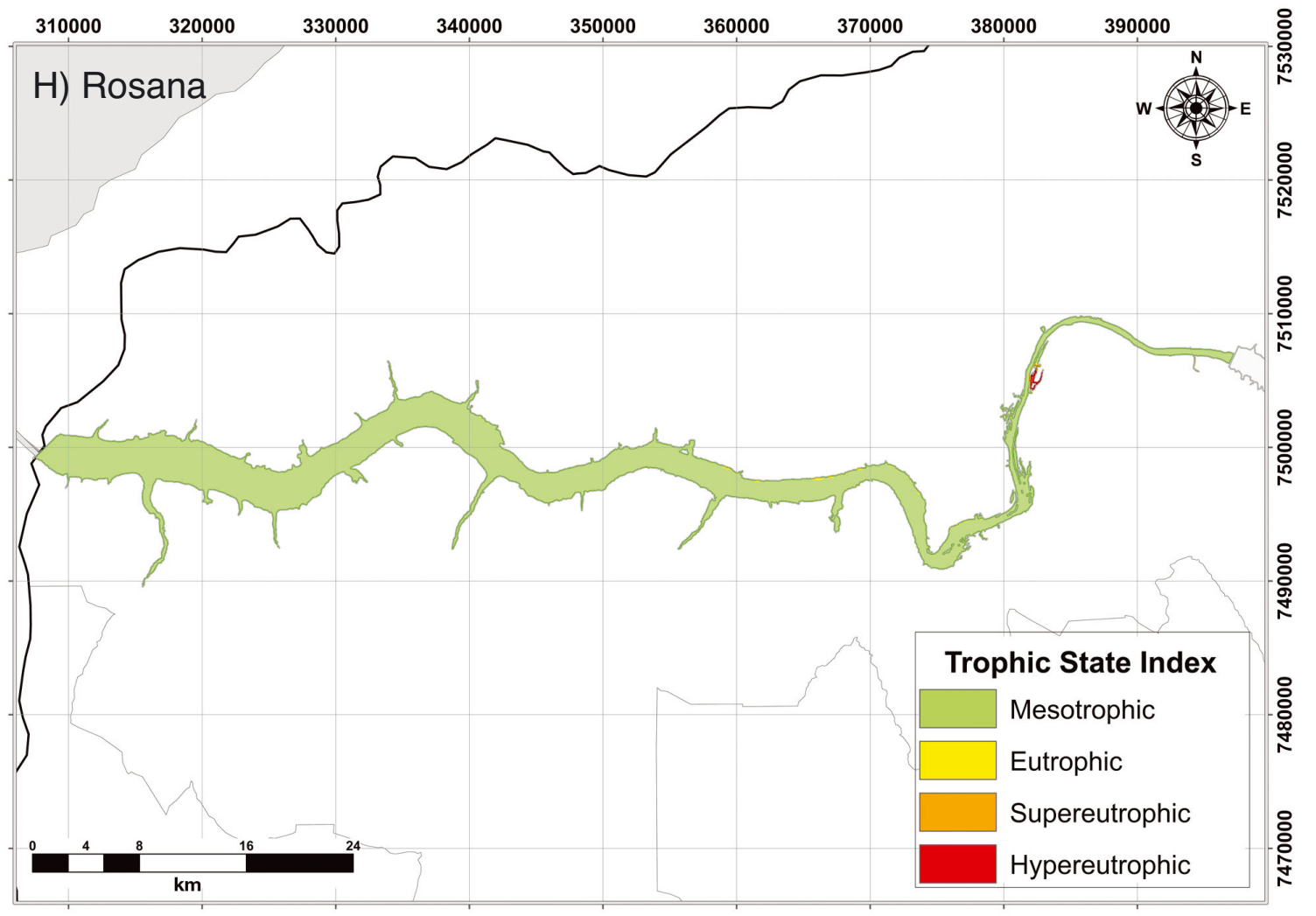

Fig. 2 (continued)

Although the TSI was calculated for the worst-case scenario and does not represent the average current conditions, the results highlight the areas with a greater tendency toward eutrophication. Therefore, the TSI should be considered when identifying areas of each reservoir that are more adequate for the establishment of aquaculture parks and predicting scenarios to estimate the environment's capacity for supporting fish farming as well as the degree of impact resulting from aquaculture on water quality parameters.

Although no environmental changes associated with nutrient increases in the bottom sediments in fish farming areas were observed, the risks of environmental impacts by this activity are real and should be constantly monitored, which is not currently occurring.

In addition, regularization and legalization of all operating aquaculture enterprises is fundamental for the controlled development of production in the Paranapanema region and in Brazil. However, the Federal Government must also create programs and strategies to minimize the technical and commercial challenges that are faced by producers and were identified in the present study. The demarcation of aquaculture parks does not represent the end of the process of establishing aquaculture in large reservoirs; rather, it is only the first step of a long journey.
Acknowledgements. We thank the GIA staff for providing access to the information about fish farming in the Paranapanema region, which was indispensable for the completion of this study. We also thank the National Council for Scientific and Technological Development (CNPq) for granting funding to A.O.

\section{LITERATURE CITED}

Abery NW, Sukadi F, Budhiman AA, Kartamihardja ES, Koeshendrajana S, Silva SS (2005) Fisheries and cage culture of three reservoirs in west Java, Indonesia: a case study of ambitious development and resulting interactions. Fish Manag Ecol 12:315-330

APHA, AWWA, WEF (American Public Health Association, American Water Works Association, Water Environment Federation) (2005) Standard methods for the examination of water and wastewater. APHA, AWWA, WEF, Washington, DC

ASTM (American Society for Testing and Materials) (1994) Water and environmental technology. ASTM, West Conshohocken, PA

Atwood HL, Tomasso JR, Webb K, Gatlin DM (2003) Lowtemperature tolerance of Nile tilapia, Oreochromis niloticus: effects of environmental and dietary factors. Aquacult Res 34:241-251

Ayer N, Tyedmers P (2009) Assessing alternative aquaculture technologies: life cycle assessment of salmonid culture systems in Canada. J Clean Prod 17:362-373

Azim ME, Rahaman MM, Wahab MA, Asaeda T, Little DC, Verdegem MCJ (2004) Periphyton-based pond polycul- 
ture system: a bioeconomic comparison of on-farm and on-station trials. Aquaculture 242:381-396

Barton JR, Floysand A (2010) The political ecology of Chilean salmon aquaculture, 1982-2010: a trajectory from economic development to global sustainability. Glob Environ Change 20:739-752

Black KD (2000) Environmental impacts of aquaculture. Sheffield Academic Press, Sheffield

Borges PAF, Train S, Dias JD, Bonecker CC (2010) Effects of fish farming on plankton structure in a Brazilian tropical reservoir. Hydrobiologia 649:279-291

Boyd CE, Tucker CS (1998) Pond aquaculture water quality management. Kluwer Academic Publishers, Norwell

Brazil (2004) Instrução Normativa Interministerial no. 6, de 31 de maio de 2004. Normas complementares para a autorização de uso dos espaços físicos em corpos d'água de domínio da União para fins de aquicultura. Ministério da Pesca e Aquicultura / Ministério do Meio Ambiente, Brasília

Brazil (2005a) Instrução Normativa Interministerial no. 7, de 28 de abril de 2005. Diretrizes para implantação dos parques e áreas aquicolas. Ministério do Meio Ambiente / Secretária Especial de Aquicultura e Pesca, Brasília

Brazil (2005b) Resolução no. 357 de 17 de março de 2005. Classificação dos corpos de água e diretrizes ambientais para o seu enquadramento, bem como estabelece as condições e padrões de lançamento de efluentes, e dá outras providências. Conselho Nacional do Meio Ambiente, Brasília

Brazil (2014) Tramitação dos processos de autorização de uso em águas de domínio da União protocolados no Ministério da Pesca e Aquicultura, entre março de 2004 e maio de 2014. Ministério da Pesca e Aquicultura, Brasília

Bremner JM (1996) Nitrogen: total. In: Bartels JM, Bigham JM (eds) Methods of soil analysis: Part 3, chemical methods. Soil Science Society of America, Madison, WI, p 1085-1122

Bueno GW, Ostrensky A, Canzi C, de Matos FT, Roubach R (2013) Implementation of aquaculture parks in Federal Government waters in Brazil. Rev Aquacult 5:1-12

Capobianco TL (2013) Tendências e perspectivas do mercado e da produção de tilápia no Brasil. Associação Brasileira da Indústrria de Processamento de Tilápia, Rio de Janeiro

Carlson RE (1977) A trophic state index for lakes. Limnol Oceanogr 22:361-396

Conley DJ, Paerl HW, Howarth RW, Boesch DF and others (2009) Controlling eutrophication: nitrogen and phosphorus. Science 323:1014-1015

Cowx IG, O'Grady KT, Welcomme RL, Bartley DM (1998) Current approaches to the enhancement of fisheries. Fish Manag Ecol 5:351-382

Cunha DGF, Calijuri Md C, Lamparelli MC (2013) A trophic state index for tropical/subtropical reservoirs. Ecol Eng 60:126-134

Da Silva NJR (2001) A extensão rural e o desenvolvimento da aquicultura. Panorama Aquicult 63:18-21

Da Silva NJR (2005) Dinâmicas de desenvolvimento da piscicultura e políticas públicas no Vale do Ribeira / SP e Alto Vale do Itajaí / SC - Brasil. PhD thesis, Universidade Estadual de São Paulo, Jaboticabal

De Silva SS (2002) Reservoir fisheries: broad strategies for enhancing yields. In: De Silva SS (ed) Reservoir and culture-based fisheries: biology and management. Australian Centre for International Agricultural Research,
Canberra, p 7-16

Demir N, Kirkagac MU, Pulatsü S, Bekcan S (2001) Influence of trout cage culture on water quality, plankton and benthos in an Anatolian Dam Lake. Isr J Aquacult 53: 115-127

Deus R, Brito D, Mateus M, Kenov I, Fornaro A, Neves R, Alves CN (2013) Impact evaluation of a pisciculture in the Tucuruí reservoir (Pará, Brazil) using a two-dimensional water quality model. J Hydrol (Amst) 487:1-12

> Dias JD, Takahashi ÉM, Santana NF, Bonecker CC (2011) Impact of fish cage-culture on the community structure of zooplankton in a tropical reservoir. Iheringia Ser Zool 101:75-84

Dotti A, Valejo PAP, Russo MR (2012) Licenciamento ambiental na piscicultura com enfoque na pequena propriedade: uma ferramenta de gestão ambiental. Rev IberoAm Ciênc Ambient 3:1-16

Duke Energy Brasil (2013) ABC da energia: a história da Duke Energy no rio Paranapanema. Duke Energy Brasil, São Paulo

Edwards P, Little D, Demaine H (2002) Rural aquaculture. Kluwer Academic Publishers, Dordrecht

> El-Gayar OF, Leung P (2000) ADDSS: a tool for regional aquaculture development. Aquacult Eng 23:181-202

> Eler MN, Millani TJ (2007) Sustainable development in aquiculture: methodology and strategies. Rev Bras Zootec $36: 33-44$

FAO (Food and Agriculture Organization of the United Nations) (2011) Technical Guidelines for Responsible Fisheries. FAO, Rome

Felisberto SA, Rodrigues L (2005) Periphytic community of reservoirs cascade in the Paranapanema river, Brazil. Acta Sci Biol Sci 27:215-223

Furlaneto FPB, Ayroza DMMR, Ayroza LMS (2006) Custo e rentabilidade da produção de tilápia (Oreochromis spp.) em tanque-rede no médio Paranapanema, estado de São Paulo, safra 2004/05. Inf Econ 36:63-69

Garcia F, Kimpara JM, Valenti WC, Ambrosio LA (2014) Emergy assessment of tilapia cage farming in a hydroelectric reservoir. Ecol Eng 68:72-79

> Gondwe MJS, Guildford SJ, Hecky RE (2011a) Carbon, nitrogen and phosphorus loadings from tilapia fish cages in Lake Malawi and factors influencing their magnitude. J Gt Lakes Res 37:93-101

- Gondwe MJS, Guildford SJ, Hecky RE (2011b) Physicalchemical measurements in the water column along a transect through a tilapia cage fish farm in Lake Malawi, Africa. J Gt Lakes Res 37 (Suppl 1):102-113

Grey J, Waldron S, Hutchinson R (2004) The utility of carbon and nitrogen isotope analyses to trace contributions from fish farms to the receiving communities of freshwater lakes: a pilot study in Esthwaite Water, UK. Hydrobiologia 524:253-262

Guo L, Li Z, Xie P, Ni L (2009) Assessment effects of cage culture on nitrogen and phosphorus dynamics in relation to fallowing in a shallow lake in China. Aquacult Int 17: 229-241

Harper D (1992) Eutrophication of freshwaters: principles, problems and restoration. Chapman \& Hall, London

Jassby AD, Cloern JE, Cole BE (2002) Annual primary production: patterns and mechanisms of change in a nutrient-rich tidal ecosystem. Limnol Oceanogr 47:698-712

Jorcin A, Nogueira M (2008) Benthic macroinvertebrates in the Paranapanema reservoir cascade (southeast Brazil). Braz J Biol 68:1013-1024 
Kumar D (1999) Aquaculture extension. In: FAO (ed) Trickle Down System (TDS) of aquaculture extension for rural development. Food and Agriculture Organization of the United Nations, Regional Office for Asia Pacific, Bangkok, p 7-10

Li N, Zhang X, Wu W, Zhao X (2014) Occurrence, seasonal variation and risk assessment of antibiotics in the reservoirs in North China. Chemosphere 111:327-335

Ling TY, Lee TZE, Nyanti L (2013) Phosphorus in Batang Ai hydroelectric dam Reservoir, Sarawak, Malaysia. World Appl Sci J 28:1348-1354

Marengoni NG (2006) Production of the nile tilapia Oreochromis niloticus (Chitralada strain) reared in cages with different stocking densities. Arch Zootec 55:127-138

Montanhini RN, Ostrensky A (2013) Nutrient load estimation in the waste of Nile tilapia Oreochromis niloticus (L.) reared in cages in tropical climate conditions. Aquacult Res 44:1-14

Nogueira MG, Jorcin A (2006) Contaminação dos sedimentos na bacia hidrográfica do Rio Paranapanema (SE, Brasil) por pesticidas sintéticos e metais e sua relação com os processos de eutrofização. In: Tundisi JG, Matsumura-Tundisi T, Galli CS (eds) Eutrofização na América do Sul: causas, consequências e tecnologias para gerenciamento e controle. IIE/DMD Propaganda e Marketing, São Carlos, p 103-118

Nogueira MG, Jorcin A, Vianna NC, Britto YCT (2006) Reservatórios em cascata e os efeitos na limnologia e organização das comunidades bióticas (fitoplâncton, zooplâncton e zoobentos): um estudo de caso no Rio Paranapanema (SP/PR). In: Nogueira MG, Henry R, Jorcin A (eds) Ecologia de reservatórios: impactos potenciais, ações de manejo e sistemas em cascata. Rima, São Carlos, p 83-126

Nyanti L, Hiii KM, Norhadi I, Ling TY (2012) Impacts of aquaculture at different depths and distances from cage culture sites in Batang Ai hydroelectric dam reservoir, Sarawak, Malaysia. World Appl Sci J 19:451-456

Editorial responsibility: Alejandro Buschmann, Puerto Montt, Chile
Pagioro TA, Velho LFM, Lansac-Tôha FA, Pereira DG, Nakamura AKS (2005) Influência do grau de trofia sobre os padrões de abundância de bactérias e protozoários planctônicos em reservatórios do Estado do Paraná. In: Rodrigues L, Thomaz SM, Agostinho AA, Gomes LC (eds) Biocenoses em reservatórios: padrões espaciais e temporais. Rima, São Carlos, p 47-56

- Petrere M (1996) Fisheries in large tropical reservoirs in South America. Lakes Reserv Res Manag 2:111-133

> Qiang J, Yang H, Wang H, Kpundeh MD, Xu P (2012) Growth and IGF-I response of juvenile Nile tilapia (Oreochromis niloticus) to changes in water temperature and dietary protein level. J Therm Biol 37:686-695

> Ramos IP, Brandão H, Zanatta AS, Zica Éd OP, da Silva RJ, de Rezende-Ayroza DMM, Carvalho ED (2013) Interference of cage fish farm on diet, condition factor and numeric abundance on wild fish in a Neotropical reservoir. Aquaculture 414-415:56-62

Reynolds CS, Huszar V, Kruk C, Naselli-Flores L, Melo S (2002) Towards a functional classification of the freshwater phytoplankton. J Plankton Res 24:417-428

> Ross LG, Falconer LL, Campos Mendoza A, Martinez Palacios CA (2011) Spatial modelling for freshwater cage location in the Presa Adolfo Mateos Lopez (El Infiernillo), Michoacán, México. Aquacult Res 42:797-807

Sulis A, Buscarinu P, Sechi GM (2011) Using reservoir trophic-state indexes in optimisation modelling of waterresource systems. Environ Model Softw 26:731-738

Tlusty MF, Snook K, Pepper VA, Anderson MR (2000) The potential for soluble and transport loss of particulate aquaculture wastes. Aquacult Res 31:745-755

> Troell M, Berg H (1997) Cage fish farming in the tropical Lake Kariba, Zimbabwe: impact and biogeochemical changes in sediment. Aquacult Res 28:527-544

> Walkley A, Black IA (1934) An examination of the Degtjareff method for determining soil organic matter, and a proposed modification of the chromic acid titration. Soil Sci $37: 29-38$

Submitted: October 23, 2014; Accepted: March 25, 2015

Proofs received from author(s): April 23, 2015 